\title{
Attitudes towards women
}

$\mathrm{T}$ he Christian sources provide us with various examples of the fact that Jewish women voluntarily converted to Christianity and, moreover, that this female conversion was honest and authentic. As matters are presented by Miri Rubin: 'Women, like children, were more likely than men to become good converts as they were seen as pliant, easily influenced, and lacking in the adamant and obstinate preoccupation with Jewish law.' ${ }^{1}$ The Christian sources speak primarily of Jewish women who were convinced of the truth of Christianity and converted to the Christian religion as the result of undergoing some miraculous experience. This point is particularly emphasized in those Christian sources describing attempts by Jews to profane the Host, the sacred bread, with depictions of Jewish women or girls (or even children) who participated against their will in attempts by their terrible fathers to harm the Host, and through it Jesus and the Christian world. When, for example, the Host is placed in a pot full of boiling water, the Jewish woman sees the image of a handsome, living child emerging from the boiling pot. She immediately understands that the divine truth is found on the Christian side rather than on the Jewish side, which is violent and tainted with sweat, and she immediately converts to Christianity. Women also discover the location of the Host which was stolen by Jews, and describe what the Jews do to profane the Host in order to cause harm to the Christian world. ${ }^{2}$ From the 1270 s on, we begin to hear of Jewish men and women in England who convert to Christianity as the result of the deliberate economic harm directed against them by the English lords in the days of Edward I, and the promise given Jews to finance their life in the Domus Conversorum ('Jewish house'). As a result, one finds in legal documents and in reports made to the king information concerning these houses, including numerous details relating to Jews and Jewesses who 
convert in order to seek financial help and assistance among the Christians, who offer them a false hope of protected Christian life. ${ }^{3}$ It is possible to learn much from these historical sources regarding Jewish women who convert to Christianity.

The first and most striking characteristic of Jewish writing about women and the question of their conversion is that the literature describes very few women who converted to Christianity of their own free will. As we have seen, the responsa literature relates to cases in which the husband converted to Christianity and his wife insisted on remaining Jewish, despite the new and problematic situation thereby created for her. In the Jewish literature of martyrdom, written by men, women who killed themselves as martyrs for Kiddush Hashem during the First Crusades are a key motif. And indeed, the chronicles reveal that women died as martyrs in almost as great numbers as did men. ${ }^{4}$ Generally speaking, when we read in Jewish writings about women who converted out, the testimonies almost always concern women who were kidnapped by Christians and held against their will, and usually succeeded in freeing themselves from the Christian captivity, whether as a result of bribery or as a result of being released by the Christians.

The halakhic background here is the need to make decisions regarding what to do with such women. As in many other situations, the halakhic authorities attempted a decision on the basis of precedent through use of an earlier, similar discussion in the Talmud. The Mishnah and the Talmud contain discussions clarifying the circumstances under which a woman who has been held captive may return to her husband (after her husband, who is obligated to redeem her from captivity, in fact did so). The discussions there revolve in practice around the question of the nature of the captors. If the captors took women in order to hold them for ransom, it is clear that they would have been protected from assault, in which case the woman may return to her husband. But if the captors were interested in murdering and despoiling, then it is suspected that the woman may have offered herself to them in order to remain alive. In that case, the issue at hand is whether or not she can return to her husband after her release from captivity. During this period of captivity, one who was forced to convert was presumed to be a captive of the first kind; hence, most of the Sages conclude that she is allowed to return to her husband. ${ }^{5}$ Moreover, a number of the Rabbis even state that one may not necessarily draw inferences from the case brought in the Mishnah and discussed in the Talmud to their own time, as the Christians who seize women in order to convert them to Christianity wished to convince them to convert to the rival religion; hence, it would make no sense for them to behave towards them in a problematic or 
licentious way. In other words, the medieval cases correspond neither to the latter nor to the former case.

In order to understand this phenomenon, one needs to analyze extensively a particular case described in some detail in both the Jewish and Christian sources. ${ }^{6}$ On 24 May 1241, the Jewish community of Frankfurt-on-Main was attacked with disastrous results. In the Jewish sources, the case is described as a particularly violent attack by Christians against a peaceful and believing Jewish community in an attempt to forcibly impose upon them conversion to Christianity. The German chronicle, by contrast, emphasizes that the upheaval was the result of an attempt by the Jewish community to prevent one of the members of the community from converting to Christianity. As a result-and due to the behavior of the Jews - we are told by the German chronicle that 'several Christians' were harmed, and some 180 Jews were killed by the sword or by fire. ${ }^{7}$ In a fire which was set by the Jews, the buildings of the communities and almost half the town burned down. Twenty-four Jews, who did not die by fire or sword, converted to Christianity.

The son of a Jew in the royal city of Frankfurt wished to receive the baptism of the Christian faith and was prevented from doing so by his relatives and friends. Therefore a public dispute ensued between Christians and Jews ... they fought very violently between them. A few Christians were killed thereby, while among the Jews 180 were, by sword and by fire which they had set in their own homes. Then the fire spread and burned nearly half the city. Perceiving imminent death, 24 Jews, who were neither slayed nor burned, let themselves be baptized. ${ }^{8}$

Among those forcibly converted was a young woman, whose name unfortunately is not mentioned, who was engaged to a man from Würzburg named Yaakov ben Yoel. She was captured and held by the Christians for a month or two, but succeeded in returning to Jewishness, and to Würzburg in order to find her fiancé and marry him. There it became clear to her that, in the interim, her intended had married another woman. The case came before the Jewish court, where there ensued a lively debate among the judges who presented a variety of opinions portraying the attitude of the leadership towards this subject. ${ }^{9}$

Rabbi Yitzhak ben Moshe, who was the leading authority in Würzburg, retroactively approved the validity of the young man's marriage. True, he argued that he had counseled the family of the groom to wait until his fiancée could be freed and only then take counsel with the leadership as to whether he could marry another woman but, as the young man had 
married despite this advice, the marriage was retroactively considered to be valid. At this point, the young woman appealed to the court (evidently) demanding that Yaakov of Würzburg divorce his wife and marry his former fiancée. According to R. Yitzhak this was impossible; because she had been held in captivity among Christians, his halakhic conclusion was that she was unable to marry the boy.

R. Yitzhak ben Moshe's opinion had a double basis. First, he relied upon the Talmudic discussion mentioned earlier in order to reach a decisive conclusion: as the captors endangered the woman's life, one may assume that she offered herself to them and therefore cannot continue in the process of marriage to her intended bridegroom. Secondly, he works on the assumption that a woman in a situation of danger and who escaped may be presumed to have used her body in order to save herself. Here R. Yitzhak ben Moshe relied upon the statement in b. Avodah Zarah 25b, 'A woman has her weapon upon her' - meaning, a woman need not fear murder by Gentiles because she is able to save herself through the use of her body. Indeed, in his eyes the fact that she managed to flee strengthened the presumption that she used her body in order to survive. R. Yitzhak ben Moshe concludes, therefore, that if she had been a married woman he would have ruled that she could not return to her husband. Hence, as an engaged woman she is similarly not permitted to return to her fiancé, and his marriage to another woman is legitimate.

Behind the halakhic validity, there emerges from the writings of R. Yitzhak ben Moshe a certain perception of the Christian religion as a corrupt and immoral one, contaminated and dangerous. Hence he admires those who died for Kiddush Hashem and refused to accept Christianity, even for appearances. He particularly celebrates those women who preferred to commit suicide for Kiddush Hashem rather than to convert to Christianity under any condition, defining the Christians as immersed in carnal desires and despising those Jewish women who were forcibly converted; he suspects the Christians of violating such women even before their conversion to Christianity. He contrasts those women who converted to Christianity with those who died for Kiddush Hashem: 'For this our hearts grieve, and it is fitting to be pained and to mourn for the righteous ones who were killed in Frankfurt. Happy are they and happy is their portion, that they sanctified with their bodies the honorable and awesome Name, and it is good for their souls, for they caused good to themselves.' ${ }^{10}$ The expressions, 'sanctified with their bodies' and 'good to their souls' indicate, more than anything else, what his opinion was of those who did not sanctify the Name with their bodies and did not do good to their souls. Hence, he sees a woman 
who was baptized to Christianity, even against her will, as one who had been free with her body, and finds Talmudic legitimacy for not requiring the man to return to his fiancée.

R. Yehudah ben Moshe ha-Cohen of Freiburg vociferously opposed the behavior of the young man and the ruling of R. Yitzhak ben Moshe. He sent letters 'to every city,' calling on them to defend this young woman in particular, and all those Jewish girls who had fallen victim to Christian coercion. His call is answered by other leaders, who in turn sent out their own letters: R. Yehudah ben Moshe ha-Cohen, R. Meshullam ben David, R. David ben Shealtiel, R. Shmuel ben Avraham of Speyer. ${ }^{11}$

These authors represent a different perception from that of R. Yitzhak ben Moshe regarding the attitude towards women who had been forced to convert. They do not deny the effort made by Christians to convert Jews, and perhaps in particular Jewish women, but they are also aware of the fact that in their day the Christian struggle had assumed a new face. The Christians are (primarily) interested in persuading women to convert to Christianity as a sign of its clear victory over Judaism; hence they intensify their efforts at convincing Jews. Even if the women were initially held forcibly by the Christians, their main intent would be to persuade them to remain Christians. Hence, in the opinion of these rabbis, as Christianity at this time was interested primarily in victory over Judaism, and the Christians made efforts to influence those girls whom they forcibly held to voluntarily convert to Christianity, from the moment these girls underwent forced baptism they were protected from sexual assault and were not subject to the threats of either physical attack or danger to life. It would be inconceivable that these young women would be raped by their Christian captors, just as it was inconceivable to suspect them of offering their favors in order to escape from death. These rabbis thus represent an approach that sees the women who were held by the Christians specifically as a sterling example of those who were unwilling to forego their Judaism. From an halakhic viewpoint they reject the Talmudic model which sees them as 'captive' or 'held in mortal danger' (shevuyah; nehbeshet la-nefashot). In their opinion, they are in a third state: that of a woman who knows that she has been unlawfully captured, has not given up hope of being freed, and hence does not lose hope but constantly longs to return to her family and to her Jewishness.

Rabbi Meshullam ben David cites the rule established by his teacher, R. Simhah of Speyer: that if the women captured by the Christians think that it is possible for them to be freed by means of pressure on their captors or by bribery, and do not consider remaining Christians, they are deserving of and entitled to return to their husbands. This view 
turns the Mishnaic discussion on its head, because these women are not threatened in a physical manner, are not subject to sexual coercion, and have not given up on returning to Jewishness. The case of the young woman discussed here, specifically, is exemplary: she remains loyal to Jewishness, denies Christianity even though it was imposed upon her to convert to Christianity, and refuses to be married to an important and wealthy Christian. Her answer is: 'I do not want him, because I am engaged to a Hebrew.' The Christians, reporting the events in all innocence, stated that she and others maintained their integrity and their Jewishness as far as possible. ${ }^{12}$ Moreover, it seems clear that these women were waiting every day to be freed from the Christians who were holding them. The fact that, in the final event, they did succeed in escaping from the Christians is taken as indication that God responded to their deserving behavior and saved them in a miraculous way. By contrast, the man-her erstwhile fiancébehaved in the worst imaginable way in that he violated his engagement agreement, an act tantamount in their opinion to violating the Herem of Rabbenu Gershom. ${ }^{13}$ R. Meshullam's words are directed primarily against R. Yitzhak ben Moshe: that one must protect these women, specifically in light of the new Christian tactic of holding them forcibly and trying to persuade them to convert to Christianity. It follows from this, not only that they ought not to be punished for failing to die for Kiddush Hashem, but that their behavior is particularly praiseworthy because they attempted to free themselves from the clutches of Christianity in whatever way possible. Moreover, the behavior of the faithless man is likely to weaken those women who find themselves in similar situations in the future. R. Meshullam emphasizes here the existence of a precedent for the present case where, because of concern regarding the Herem of Rabbenu Gershom Meor ha-Golah, the man was forced to divorce the woman he had married and to marry the one whom he had originally promised.

R. Yehudah ben Moshe ha-Cohen's words are primarily intended to strengthen the Jewish self-image. The Jewish women are pure, and the Christian captivity does not touch them. His words are formulated carefully: the women were persuaded (to convert) with the threat of the sword, but throughout the entire time their hearts were directed to their Heavenly Father. He refers to them with the term, banot mehutavot, 'daughters like corner pillars.' This term is one of great significance, based upon associations with a verse in Psalms describing a man's sons and daughters: 'May our sons in their youth be like plants, full grown; our daughters like corner pillars, cut for the structure of a palace' (Psalms 144:12). Since the eleventh century, the widely accepted interpretation of the phrase 'our daughters 
like corner pillars, cut for the structure of the palace' is that it describes the appropriate manner of behavior of Jewish women concerning purity in matters of intimate relations. Rashi, in his commentary on the Talmud, explains the term by noting that it combines the reference to 'olives' in the above-mentioned verse from Psalms with the 'olives' mentioned in Zechariah 9:15: 'drenched like the corners of the altar.' The 'sprinklers' in the Sanctuary and in the Temple were vessels used for sprinkling blood upon the altar. In Rashi's view, the sprinkler filled with the blood of the sacrifice is compared to a married woman, filled with desire and awaiting her husband alone, and keeping herself for her husband, be things as they may. According to his view, such women are the foundation upon which there stand the walls of the Sanctuary, the walls of the Temple and, by extension, the entire structure of the Jewish people. That is to say, R. Yehudah emphasizes the standing of pure, upright Jewish women as the walls (or pillars) of the Sanctuary. ${ }^{14}$

R. Yehudah ben Moshe ha-Cohen and R. Shmuel ben Avraham, both of whom were among those who attacked the ruling of R. Yitzhak ben Moshe, each composed a memorial poem concerning the event that had taken place in Frankfurt. These liturgical poems were intended to be recited on the anniversary days of the slaughter, while mentioning the names of those who died 'sanctifying the Name.' These piyyutim describe the willingness to die, the attachment to the Jewish faith, and the attempt by the Christians to impose their religion by force and thereby achieve victory. The list evidently names those who died out of active opposition to Christian coercion, while the others were put to death by the sword or burnt to death in a fire that broke out. ${ }^{15}$ This was unlike the writings of R. Yitzhak ben Moshe, who contrasts those women who were forcibly converted to Christianity and remained alive against the noble behavior of those who did not agree to convert and died a glorious death. These two authors do not emphasize this element at all. Their piyyutim describe the Jewish community as a single group, its members having identical behavior, both men and women. R. Yehudah ben Moshe goes even further: in his poem, he describes the women who died for Kiddush Hashem as 'corner-pillar daughters,' the same term used in his responsum to refer to those women who were forced to live as Christians and returned to Judaism with all their heart. In this piyyut, he expresses his view that, in practice, there is no difference between those women who died for Kiddush Hashem and those who were forcibly converted to Christianity but continued to observe Judaism. Both groups are certainly pure from the sexual viewpoint: some of them chose to die for Kiddush Hashem, while others were forced to convert but even then 
preserved their purity and their faith. Likewise R. Shmuel ben Avraham, in the piyyut which he wrote, glorifies the men and women who die for Kiddush Hashem, but in his responsum attacks the distinction drawn by R. Yitzhak ben Moshe regarding those women who were forced to live as Christians and then returned to their Judaism by using identical terms for both. As against the halakhic argument invoked by R. Yitzhak, R. Shmuel writes quite simply, in a brief sentence, 'I do not know who allowed him to see daughters of Israel as presumed to be harlots. ${ }^{16}$

Another respondent, R. David ben Shealtiel, criticized primarily the halakhic viewpoint of R. Yitzhak Or Zaru'a. He reiterated what Rabbenu Hannanel had already explained, that the precedents brought in the Talmud relate, in their own time (i.e., the Middle Ages), only to those women married to kohanim (members of the hereditary 'priesthood'), thereby greatly limiting the applicability of such precedents. As for the fact that the woman had spent a certain period of time living among Christians as a Christian woman, R. David ben Shealtiel emphasized the view articulated in the Talmud by the amora Ravva: 'If it [i.e., her relations with a gentile man] began through coercion, [even] if was subsequently done willingly, she is permitted (to her husband).' In the present case, it clearly began with coercion, and also continued under duress. He adds that it is well known that in France Rabbenu Tam allowed the return of women to their husbands after they had spent a period of time among Christians. Finally, he cites the opinion of R. Eliezer ben Yoel ha-Levi (Rabya'h; beginning of the thirteenth century) stating that, wherever there are Christian judges in the city, one may not assume that Christians violate Jewish women being held by them, and therefore one may not assume that the Christians violated them sexually. As for the young man who hastened to marry another woman despite the fact that he was already engaged to the former, R. David ben Shealtiel states that:

This one who was unfaithful to his fiancée is deserving to be stretched upon the post and made to pay a serious fine, and I decree upon him under sanction of ban and excommunication to return to his fiancée; and if he has married the second one he must divorce her under the order of the community, and if he refuses he shall be subject to the ban and excommunication of the community; and if he adds to his previous sin the crime of marrying or betrothing the second one, let him incline his ear to the words of the Sages. ${ }^{17}$

It should be noted that, notwithstanding the strident opinion expressed in this case against the young man and on behalf of the young woman, 
the view that women ought to sacrifice their lives and refuse to agree to conversion even at the cost of their lives continued to be the predominant view of many of the men. This is clearly expressed by R. Asher ben Yehiel (Rosh) at the end of the thirteenth century. Despite the fact that, in his opinion, these women are permitted to return to their husbands, he judges them strictly in terms of values, referring to them as 'women who did not have the strength to stand in the palace of the king.' This is a clear allusion to Daniel 1:4: 'youths without blemish, handsome and skillful in all wisdom, endowed with knowledge, understanding learning, and competent to serve in the king's palace, and to teach them the letters and language of the Chaldeans.' Those able 'to serve in the king's palace' are those who are prepared to sacrifice themselves for their faith. According to the Rosh, these women must regret that they converted their religion, even under duress, even more so than those women who voluntarily converted to the Christian religion, for specifically in the case of forcible attempts to change one's religion one must be stubborn and die a martyr's death. ${ }^{18}$

The problematic case reflects a state in which a woman who was taken captive by Christians refused to become integrated within the Christian world in which she was forced to live and, despite the temptations offered by Christian society, insisted upon returning to her Jewishness. But what if the woman forced to live within the Christian world feels so good about it that she does not hasten to return to the Jewish world? Such a case was in fact brought to our attention regarding a woman who was captured by Christians and forcibly converted to Christianity, who went on to live in marriage with a Christian man. After a certain period of time, her parents succeeded in bringing her back, and she returned to living with her Jewish husband. It becomes clear that, in practice, the woman has returned to her husband, and the society around her accepts this. However, one member of the community was troubled by this situation and sent an inquiry about it to the Rabbinic judges: this woman had lived with a Gentile for a certain period of time; how then can she return to her Jewish husband? 'And I asked them: Who permitted her to her husband [because a woman who has been unfaithful to her husband is forbidden to him thereafter]? ... And now, our Rabbis, teach us the way in which we should walk, for I do not know how to rule in this matter!' The question is, in practice, how to relate to this woman in light of the Talmudic precedents. ${ }^{19}$

The case here involved a woman who had been forced to convert under threat to her life, but who did not give herself over to death for Kiddush Hashem, subsequently remained in Christianity of her own free will, lived intimately with a Christian man, and 'behaved licentiously regarding all 
the prohibitions of the Torah.' Is such a woman comparable to one who abandoned her husband and now lives with another man, in which case she is clearly forbidden to return to her husband? Or shall we treat such a woman on the basis of her 'beginning' — i.e., as one who was taken captive unwillingly, and conclude that she deserves to return to her husband? The degree to which this matter was problematic may be seen on the basis of the answer, which may be understood in both directions: the author of the responsum is concerned that, if we permit a situation in which a woman who had voluntarily lived with a Christian man returns to Judaism and lives with her Jewish husband as before, merely because she had originally been taken captive forcibly by the Christians, this will be the beginning of a 'slippery slope' ('we will destroy the entire structure'). This is particularly so in light of the fact that she did not attempt to escape or slip away from the Christians immediately. However, at the end of his words he withdraws somewhat from his uncompromising position and returns the question to his interlocutor: 'I have not heard the halakhah regarding this subject from my rabbis, and you are wise like an angel of God.' 20

This case, like several others, reveals what the sources wished to obscure (if not to conceal entirely): namely, that there were Jewish women who converted to Christianity of their own free will and lived with Christian men. We become aware of such cases only when the women wish to return to their Jewishness, or even wish to return to their Jewishness together with the Christian man with whom they live who is now interested in conversion to Judaism, in which case the reality becomes evident in the course of the halakhic discussion.

The earliest source concerning this matter is a responsum attributed to Rashi (end of the eleventh century, northern France), concerning a married woman who lives willingly with a Christian man, and is now interested in returning to live with her husband. Is she permitted to him or not $?^{21}$ This responsum is extremely interesting, over and above the brief and clear statement that a married woman who converted to Christianity and lived with a Gentile is forbidden to her Jewish husband-first of all, in the use which it makes of the case of Queen Esther in order to prove this point (a subject to be discussed in the next example); secondly, in the assumption that a woman converts to Christianity because of her desire to live with a Christian man, and not because she is convinced of the truth of the Christian religion. It does not seem possible to our author that a woman would be convinced of the Christian truth; hence, her reason for abandoning the Jewish religion must be her desire to indulge in sexual relations which are forbidden by the Jewish religion but permitted 
according to Christianity. This substantive position, one of a positive and value-based self-definition as opposed to the other religion, is based upon a passage in the Talmud: 'R. Yehudah said in the name of Rav: Israel knew that idolatry has no substance; hence, they did not engage in pagan worship except to permit themselves sexual licentiousness in public' (b. Sanhedrin 63b). Thus, a woman who converted to Christianity is perceived as one who had surrendered to her sexual lust. ${ }^{22}$ At the end of the responsum, its author takes care to note that there are those who think differently, whom he refers to as 'chatterers': 'There are those who chatter regarding this matter, and there is naught of substance to their words... and one may not be lenient.' ${ }^{23}$ That is, the decisive response that 'one may not be lenient,' and the reference to those who differ as 'chatterers,' indicates a different attitude towards these women. A debate of this type takes place between the grandson of Rashi, R. Ya'akov ben Meir Tam, and his disciple, R. Yaakov ben Mordechai, regarding an interesting case in which a woman converts to Christianity voluntarily, lives with a Christian, and now wishes to return to Judaism, along with the Christian man, who is interested in converting. Such a case was brought before Rabbenu Tam (d. 1171), who states that she may return and is even permitted to marry the same Christian once he converts. ${ }^{24}$

Rabbi Ya'akov Tam's remarks relate to a discussion in the Talmud regarding the question as to whether a woman threatened with rape by non-Jews needs to resist to the point of death (i.e., effectively, to commit suicide). Or, to be more precise, is one required to inform women that the case of sexual violation by a Gentile does not disqualify her from returning to her husband, and is not a cause for sacrificing her life? This discussion refers in practice to jus primae noctis, mentioned in the Talmud with respect to the Hasmonean or Roman period; the answer given in the Talmud is that one ought not to publicize this fact, as there may be women who would consent willingly, and hence would not be allowed to return to their husbands. ${ }^{25}$ The question asked in the Middle Ages concerning this matter was whether the principle that one is required to sacrifice one's life in three cases (idolatry, sexual licentiousness, and bloodshed) also subsumes the case of rape by a Gentile.

Rabbenu Tam states, in all simplicity, that the sexual intercourse of somebody who is not a Jew is not considered giluy arayot, a forbidden sexual act, because their coitus cannot be described as such because they are compared to animals. His argument for this is based upon Ezekiel 23:20: 'and their issue is like that of horses,' a verse referring to Gentiles. He cites in proof the case of Queen Esther. The Talmud asks the question why, 
regarding Esther she did not sacrifice her life, despite the fact that her act of cohabiting with the Gentile King Ahasuerus was one that was publicly known, and as such an act for which one is required to sacrifice one's life (b. Sanhedrin 74a). Because the question is raised regarding the public nature of the act and not regarding it being a prohibited sexual act, Rabbenu Tam infers that the Talmud assumes that in the case of Esther there was no giluy arayot, because the intercourse of the Gentiles is not considered as such at all, because they are like animals. This conclusion eliminates the problem entirely. If the sexual act of a person who is not Jewish is not considered as a human act, then there is no reason to apply the rule that one who was unfaithful to her husband is prohibited to both her husband and her lover; there is likewise no problem involved regarding a woman who was raped by a Gentile; and there is also no problem for a Jewish woman who lived with a Gentile man to return to Judaism and also to marry the same man after he converts.

This approach of Rabbenu Tam is unacceptable to Rabbi Yaakov ben Mordechai. As he understands matters, the decisive factor is the will of the woman, and if the woman voluntarily agreed to intercourse she is prohibited to her husband. He also brings proof (among other things) from the case of Queen Esther. According to the medieval explanation, Esther was Mordechai's wife before she came into Ahasuerus' harem, and she continued her relations with Mordechai until she set out to seduce Ahasuerus of her own intiative, at which point she said, 'If I perish, I perish' (Esther 4:16) — that is to say, from this moment on she was giving herself to Ahasuerus of her own free will; hence, from that point she was considered unfaithful to Mordechai and therefore forbidden to him, despite the fact that Ahasuerus was not a Jew. We conclude from this that adultery with a Gentile renders a woman forbidden to her husband, and that his intercourse is not treated as analogous to that of an animal.

Another woman discussed in this context is Yael, wife of Heber the Kenite (b. Sanhedrin 105b), concerning whom it is said, 'Most blessed of women in the tent is Yael' (Judges 5:24). Regarding the question, to which women is she is compared here, the Talmud answers, 'Sarah, Rebecca, Rachel and Leah' (b. Nazir 23a). But how is it that Yael is considered so blessed? Did she not have forbidden sexual relations with Sisera? Yael was not raped, as Sisera did not force himself upon her; to the contrary, he was completely dependent upon her and tried to hide himself with her in order to save himself from Barak who was chasing him. The explanation given is that Yael's act-i.e., the transgression involved in having sexual relations with Sisera — was done in order to kill him and thereby save Israel, 
indicating that 'A transgression for its own sake is greater than a mitzvah for its own sake. ${ }^{26}$ That is, Yael performed a transgression in order to save her people; hence, she is even more highly praised than the mothers of the nation!

But at the end of the thirteenth century it is emphasized that one who converted of her own free will and lived with a Christian is forbidden to her husband if she returns to Judaism; as everything depends upon the woman's will, it is assumed that, when she converted to Christianity, she did so, not because she found Christianity attractive as a religion, but because she wanted to be unfaithful to her husband. In this manner, the argument that the woman converted because she recognized Christianity as the true religion is rejected. But from the sources the prevalent reality becomes clear: husbands were willing to accept their wives back when they returned from the Christian world, even when they knew that this was contrary to the halakhah and that the religious leadership and the judges were opposed to this. Rashi himself stated that such a woman must receive a divorce from her husband. Some hundred years later, R. Eliezer ben Yoel ha-Levi testified that his father permitted a married woman who had willingly spent a certain period of time in the home of a Christian man to return to her husband. But particularly, the understanding that the woman is forbidden to her husband is shown by the explicit anger of R. Isaiah di Trani in the middle of the thirteenth century regarding such a situation: 'I have heard of a great ill that is done in your community that a married woman who had become an apostate and stayed among the Gentiles many days thereafter returned and resumed relations with her husband as it was before.' This also applies to the previous case which, it is true, concerns a woman who was forcibly taken captive by the Gentiles, but thereafter remained with them of her own free will and lived with a Gentile, who now returned and lived with the man who had previously been her husband. ${ }^{27}$

At the beginning of the thirteenth century, Rabbi Yitzhak of Nicola (apparently Lincoln) writes of 'a woman who willingly had illicit relations with a Gentile and became an apostate, and thereafter recanted [returned to Judaism] and went to a remote country, whose mother complained that her son-in-law [had since] married another woman but would not agree to divorce her daughter [the first wife], who had since repented. ${ }^{28}$ In other words, there existed a phenomenon of Jewish women who lived with Christian men. Moreover, generally speaking the husbands were willing to accept them back as their wives once they returned to the bosom of Judaism.

The tension between halakhah and reality also emerges regarding the question as to what happens if both partners converted together to 
Christianity, and now wish to return to Judaism and continue to live as husband and wife. This question was raised at the end of the twelfth century in northern France, and again a century later in Germany. Rabbi Samson of Sens (d. 1230) responded with much reservation regarding such a case brought to his attention, in which one of the Sages stated that the woman is presumed to have been sexually loose, even though her husband was with her, and therefore is forbidden to him following his return to Judaism. R. Samson emphasizes that, even among non-Jews, women are not usually sexually licentious, and therefore it seems unreasonable to assume that a Jewish woman who lived among Christians would be of a lower moral level than the Christians themselves. Moreover, he stresses the fact that both of them were 'repentants' and wished to return to Judaism - a fact which indicates that, in his opinion, they did not violate Torah prohibitions during the period when they were Christians. It is clear that the essence of his decision is the desire to allow them to return to Judaism, and is clear that they wish to return to Judaism in order to live together as a Jewish couple. It they were to be separated, perhaps this would prevent them from returning to Judaism.

In Germany, at the end of the thirteenth or the beginning of the fourteenth century, the debate on this matter revolves around the salient halakhic points regarding this subject. However, the attitude of anger towards the apostates, particularly towards the women who had converted, is strongly emphasized. We are dealing here with a couple who had abandoned Judaism and chosen to live among Christians, and it is possible that the sexual 'freedom,' specifically, may have been what attracted them. This is particularly true, in the leadership's opinion, with regard to the woman. One may not rely upon a woman who has converted to Christianity to maintain her chastity for her husband, for 'If she does not fear the Holy One blessed be He, why should she fear her husband?' Nevertheless, the reality is reflected in their decision. Notwithstanding these views, such couples return together to Judaism and once again live together as Jews. It seems clear that the leadership was unable and unwilling to separate them. In the words of one of the authors of the response: 'So as not to reject them so that they return to their bad ways, I saw fit that one ought not to be strict with them. ${ }^{29}$

Rabbi Meir ben Baruch (the Maharam of Rothenburg) who, as we have seen, was very strict in his approach towards men who had converted to Christianity and now wished to returned to Judaism, was much more lenient with women in Dukenhausen (Rockenhausen?) who found themselves in a similar situation. He accepted the testimony of the women themselves, as 
well as permitting them to return to their husbands. He emphasizes that 'they never practiced idolatry, but the priest said his abomination to the Gentiles and they remained silent. ${ }^{30}$ This is the dominant approach in the halakhic rulings of the end of the thirteenth and beginning of the fourteenth centuries. All of these Sages see a married woman who was captured by Christians and thereafter released as one who should be allowed to return to her husband without difficulty; in the case of divorce, she is entitled to the full sum of her ketubah. As we observed earlier, they were also willing to distinguish what happened in their own period from the seeming precedent from the Talmud. The Christians are interested in these women as potential Christians; hence, they will protect them and will not assault them sexually. The rabbis emphasize that these women were forced to convert under coercion and that 'it is their constant intention to return to Judaism' - that is to say, they have not given up hope on the possibility of returning to Judaism, and even endangered themselves by their attempts to return. One may therefore accept their testimony regarding one another, even from the period during which they were 'Christians' under coercion. ${ }^{31}$

Was the approach here one that was built upon reality? Did women convert to Christianity less often than men? As we do not have any evidence one way or another, I would like to emphasize a point related to their self-definition as Jews and to the mentality in relation to women. The Jews in the Middle Ages believed that conversion to Christianity, even under force and even for a brief period of time, created a substantive blemish in the personality of the convert and in the transmission of their qualities. As I understand the matter, medieval Jewish society believed that women were responsible for transmitting the 'genetic' qualities of Jewishness to their children; hence, there was a constant worry about the situation of women and the dangers involved in their being drawn close to Christianity. The insistence upon searching out family 'blemishes' was directed primarily towards future brides, particularly if they belonged to families in which there had been apostates or forced converts to Christianity. ${ }^{32}$ In the mid-twelfth century, in northern France, Rabbenu Tam received a letter stating that in a certain family there was a daughter who had been married to a man who converted to Christianity and that she had received a divorce from him; however, one of the judges refused to ratify the get and it was now difficult for the woman to remarry. Rabbenu Tam answers that, if there is a divorce written by an apostate, the woman may marry whomever she wishes, adding that, 'Now you, the generous father of the daughter, marry your daughter to one who is fitting to her, for there is no need to pay any attention to the words of scandal-mongers. ${ }^{33}$ 
In other words: society was fearful of any connection with a person who had been touched in whatever way by the Christian religion. One hundred years later, in Germany, there was a case involving a family whose son was engaged to a girl who had fallen into the captivity of Christians, so they quickly married him to someone else. They evidently feared that, as the girl had been in Christian hands, she was contaminated in some way and, as the fiancée of their son, he would have to marry her should she be released, and the blemish would enter into their family. The rabbis sought to mollify fears regarding such women and were therefore insistent upon emphasizing the role of women in martyrology, on the one hand, and moderating the attitude towards women who had been forced to convert but had returned to Judaism, on the other.

\section{Notes}

1 M. Rubin, Gentile Tales: The Narrative Assault on Late Medieval Jews, London 1999, p. 84 .

2 See Rudolph of Schlettstadt story-Historiae memorables. Zur Dominikanerliteratur und Kulturgeschichte des 13 Jahrhunderts, ed. E. Kleinschnidt, Cologne 1974, No. 9, pp. 53-55; R. Po-chia Hsia, 'Witchcraft, Magic and the Jews in Late Medieval and Early Modern Germany,' in: From Witness to Witchcraft: Jews and Judaism in Medieval Christian Thought, ed. J. Cohen, Wiesbaden 1997, pp. 419-433; Rubin, Gentile Tales, pp. 84-86.

3 M. Adler, Jews of Medieval England, London 1939, pp. 279-339; R. C. Stacey, 'The Conversion of Jews to Christianity in Thirteenth-Century England,' Speculum 67 (1992), pp. 263-283; R. Mundill, England's Jewish Solution, Cambridge 1998, pp. 100-103, 275-276.

4 S. Salfeld, Das Martyrlogium des Nürnberger Memorbuches, Berlin 1938; S. Noble, 'The Jewish Woman in Medieval Martyrology,' Studies in Jewish Bibliography, History and Literature in honor of I. E. Kiev, ed. C. Berlin, New York 1971, pp. 347-355. See also this article in: Proceedings of the Fifth World Congress of the Jewish Studies, 2 (1972), pp. 133-140; S. Goldin, The Ways of Jewish Martyrdom, Turnhout 2008, pp. 112-117.

5 b. Ketubot 26b Rashi and Tosafot there; Tosafot Avodah Zarah 23a s.v. teda; Rashi, Avodah Zarah 25b s.v. Beisah; Tosafot there s.v. ica benyehu; Haggahot Maimuniyyot to Hilkhot Biaha 18a; Meir ben Baruch, Sheelot u-Teshuvot ha-Maharam, Prague edition, ed. M. A. Blakh, Budapest 1895, No. 1,020; G. J. Blidstein, 'The Personal Status of Apostate and Ransomed Women in Medieval Jewish Law,' [Hebrew] Shenaton ha-Mishpat ha-Ivri 3-4 (1976-77), pp. 35-116.

6 S. W. Baron, A Social and Religious History of the Jews, 18 vols. Philadelphia 1952-83, Vol. 9, pp. 143-144; Blidstein, 'The Personal Status of Apostate,' note 200; Goldin, The Ways of Jewish Martyrdom, pp. 304-310; R. Furst, 
'Captivity, Conversion and Communal Identity: Sexual Angst and Religious Crisis in Frankfurt, 1241,' Jewish History 2 (2008), pp. 179-221.

7 Names of the Dead: S. Salfeld, Das Martyrlogium des Nürnberger Memorbuches, Berlin 1938, pp. 13-14; 125-126.

8 Monumenta Germaniae Historica - Scriptorium, Vol. 16, pp. 26-40, the English translation from Frust, 'Captivity, Conversion, and Communal Identity,' p. 181.

9 The Responsa: Responsa et Decisiones, ed. E. Kupfer, Jerusalem 1973, pp. 282-289. Hayim ben Rabbi Yitzhak, Responsa, Leipzig 1860, No. 221; Mordechai Ketubot, No. 286.

10 Isaac ben Moses, Sefer Or Zarua, 4 vols. Zhitomir 1862, Vol. 1, No. 747, p. 213.

11 E. E. Urbach, The Tosaphists: Their History, Writings and Methods, Jerusalem 1980, pp. 433, 526-527.

12 Hayim ben Rabbi Yitzhak, Responsa, No. 221, p. 72.

13 A Rabbinic edict prohibiting a man from marrying more than one woman or from divorcing a woman against her will. See S. Goldin, Jewish Women in Europe in the Middle Ages: A Quiet Revolution, Manchester 2011, pp. 99-105.

14 Rashi at Pesahim 87a s.v. ve-malhu; b. Bava Batra 75a; Midrasch Tehillim (Midrash on Psalms), ed. S. Buber, Wilna 1892 [repr. Jerusalem 1966], No. 145. Like R. Yehudah ben Moshe ha-Cohen, this expression is also used by Yalkut Shimoni, a midrash written during this same period, Yalkut Shimoni, Vol. 1, Jerusalem 1980, No. 888.

15 S. Baranfeld, Sefer HaDemaot, 3 vols. Berlin 1924-1931, Vol. 1, pp. 299-305, Vol. 3, p. 332; Salfeld, Das Martyrlogium des Nürnberger Memorbuches, pp. 329-331; A. Haberman, ed., Sefer Gezerot Ashkenaz ve-Zarfat, Jerusalem 1945, pp. 176-178. R. Yehudah ben Moshe ha-Cohen wrote Va-etonen va-ekonen marah ve-alyah; R. Shmuel ben Avraham wrote Aishev bekhi va-nehi. See Goldin, Jewish Women in Europe in the Middle Ages, pp. 39-42.

16 Teshuvot uPsakim, p. 170.

17 Mordechai Ketubot, No. 286.

18 The text begins with the word 'last year,' that is, the discussion is occurring during the course of the first year following the event. Asher ben Yehiel, Shut haRosh, ed. S. Yudelov, Jerusalem 1994, No. $32 \S 8$.

19 Mordechai Kiddushin, No. 568

20 It is not clear when this inquiry and response were written, nor by whom. Urbach conjectures that the questioner was R. Joseph of Orleans Bekhor Shor, and that the respondent was someone called Rabbenu Tam. This places the question and answer in the middle of the twelfth century or shortly thereafter. The reasons given are not convincing and the answer does not reflect the opinion of Rabbenu Tam, as we shall see below. Urbach, The Tosaphists, pp. 132-133.

21 The source begins with the words: 'I found in Sefer ha-Pardes in the responsa of Rashi, of blessed memory,' but there is no trace of this responsum in the extant edition of Sefer ha-Pardes. It nevertheless seems to me that the source 
was written by Rashi. See Mordechai Ketubot, No. 286; Blidstein, 'The Personal Status of Apostate,' pp. 58-59.

22 In this respect, he differs from Rav, whose remarks were directed, in my opinion, to men and not to women.

23 Mordechai Ketubot, No. 286.

24 In the source that disagrees with R. Yaakov ben Meir, Rabbenu Tam, there appear the initials Rib'am, which may also refer to the name R. Yitzhak ben Meir; if so, we have here a dispute between two brothers, Rashi's grandsons. However, this interesting detail does not change the time frame of the discussion. See Tosafot Ketubot 3b s.v. ve-lidrus lahen.

25 Tosafot Ketubot 3b s.v. ve-lidrus lahen.

26 Tosafot Ketubot 3b.

27 Shlomo ben Isaac (Rashi), Responsa Rashi, ed. I. Elfenbein, New York 1943, No. 171. Rashi cites a woman who 'became a convert for a long time and was forbidden to her husband, and after some time returned to practice the ways of Judaism. She needed a get, but her husband was elsewhere.' Rabbi Yoel ha-Levi was asked whether a Jewish woman who went voluntarily with an idolater and stayed there three days in his home, and was then removed with a bribe, was permitted to return to her husband. He answered that she was permitted to return to her husband, in Isaac Ben Moses, Sefer Or Zarua, Vol. 1, No. 61; Mordechai Ketubot, No. 286. R. Isaiah di Trani, Teshuvot RID, Jerusalem 1967, pp. 285-286, No. 58. See A. Haverkamp, 'Baptised Jews in German Lands during the Twelfth Century,' in: Jews and Christians in Twelfth Century Europe, eds. M. A. Signer and J. Van Engen, Notre Dame, Ind. 2001, pp. 269-273 (and notes 98-115).

28 Moses of Zurich, Sefer haSemak miZurich, ed. I. J. har-Shosanim, 3 vols. Jerusalem 1973, Vol. 2, p. 120, No. 233; Urbach, The Tosaphists, pp. 509-510.

29 Meir ben Baruch, Sheelot u-Teshuvot ha-Maharam, Prague edition, No. 1,020; Meir ha-Kohen, Teshuvot Maimuniut to Moses ben Maimon, Mishneh Tora, Jerusalem 1952, Hilcho Isurei Biaha No. 18 [a].

30 Meir ben Baruch, Sefer Sharei Teshuvot Maharam b. Barukh, ed. M. A. Blakh, Berlin 1891, No. 80, pp. 117-188; Blidstein, 'The Personal Status of Apostate,' pp. 99-100.

31 A. Agus, ed., Responsa of the Tosaphists, New York 1954, s. v. 126, 127, pp. 235-237.

32 Numerous references to this problem appear in Judah b. Samuel he-Hasid, Sefer Hasidim, ed. J. Wistinetzki, Frankfurt am Main 1924, see Nos. 1,900, 1,898, $1,097$.

33 Ya'akov ben Meir, Sefer haYasharle Rabbenu Tam: Heleq haShe'elot vehaTeshunot (Responsa), ed. S. F. Rosenthal, Berlin 1898, s.v. 25-26, pp. 42-45; Ya'akov ben Meir, Sefer ha-Yashar (News), ed. S. Schlesinger, Jerusalem 1959, pp. 448-449; Tosafot Gittin 34b s.v. vehu; Urbach, The Tosaphists, p. 121; Blidstein, 'The Personal Status of Apostate,' pp. $86 \mathrm{ff}$. 